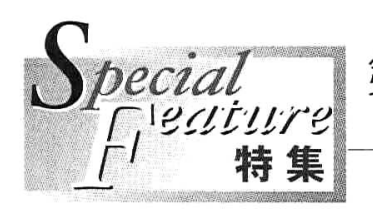

\title{
今後の学術会議への 期待
}

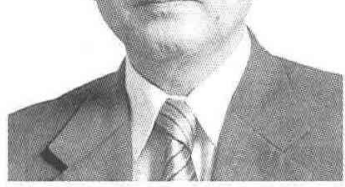

第19期までの活動を振り返りつつ

祖田 修

そだ おさむ 1939年生

第19期日本学術会議第6部部長、福井県立大学学長、京都大学名誉教授 尃門：農学原論、地域経济論

\section{はじめに}

いよいよ日本学術会議の新たな出発となり、7部 制から3部制へと変わり、体制も内容も一新する。 私は最後の第6部長として、不安と期待の入り混じ った気持ちであるが、見守っていきたいと思う。私 は農業経済学研究連絡委員会 (以下研連) より第17 期の会員として推薦され、当初一期犬゙けのつもり が、つに8年3カ月三期の務めとなってしまった。 この間日本老代表する各分野の先生方と、総会や各 種委員会での議論、シンポジウムでの報告と討論の 機会があり、また『学術の動向』にも隋分原稿を執 筆させてもらい、ありがたいことであった。思えば 大变多忙であったが、私自身は学問的にも人間的に も成長させていただいたように思う。

第20期に向けての種々の経緯注第17期頃より始 まり、多くの議論を経て第20期が生まれた。そこ で、以下第19期を中心とするが、私の個人的なこ とも含めて、若干その経緯にふ机ることで、日本学 術会議の動き、第6部の活動の流れ等を紹介する形 をとらせていただきたいと思う

\section{第17〜18期のこと}

私は第17期に初めて日本学術会議に参画したが、 当初はよくわからないことも多く、比較的平凡な会 員として過ごした。ただ研連としての委員会やシン
ポジウムは積極的に開催した。日本学術会議には予 算がなく、時には自腹を切って研連委員外の演者を 頼んで、シンポジウムを盛り上げたこともある。

何よりも私にとって有益であったのは、この頃吉 川弘之会長は、俯酶的視点からの学術の再生、総合 的視点の重要性を訴えられ、「科学のための科学」 から「社会のための科学」を主張された。それと関 連して、総会や委員会などで科学論の検討がなされ たことだ。それによって、私は2000年夏刊行に向 けて、農学の科学論としての『農学原論』の仕上げ を急いでいたが、参考になり教えられることが多か った。

第 18 期に入って、私自身は幹事に推され、活動 の場が広くなり、積極的に取り組んだ。特に農林水 産省から日本学術会議に諮問が舞い込み、「農業・ 森林の多面的機能」について検討が要請され、私が 特別委員会の委員長を務めさせてもらった。政府か らの諮問は30数年ぶりのこととされ、日本学術会議 の新たな方向の芽を示唆する側面もあった。この多 面的機能の検討は、農学系だけだと我田引水的にな りがちだが、第1部 (文学) から第7部 (医学)まで、 全領域から委員が加わり、また運営番議会や総会で も議論してもらった。そこでは多くの貴重な知見が 示され、それを生かすことが出来た。比較的評判も よく、農水省もパンフレットを作成して活用した。

これに関連して、日本学術会議の総力を挙げて 
取り組まれた「日本の計画」委員会に参加すること が出来たが、これは吉川弘之会長、黒川清副会長 のリードの下に、高邁かつ内容の濃い報告書とな った。その他第18期第6部では、「真の循環型社会 の構築」を目指す特別委員会が組織され、熊沢喜 久雄会員を中心に、レベルの高い報告書がまとめ られた。

その後第19期になって、同じく農水省より「水産 業、漁村の多面的機能」の検討を要請する諮問が来 た。第6部を中心に再び特別委員会を組織、佐藤晃 一委員長を中心に取りまとめを行った。多面的機能 論は、経済学における「市場の失敗」を基礎概念と し、欧州連合 (EU) に始まった議論であるが、農・ 林・水の全般にわたって議論が整理されたのは、お そらく世界でも初めてで、意義のあることであった と思う。

また第18期には、下記の日本学術会議再編の動 きを受けて、農学の未来に対する懸念が広がってい た。そこで第6部会員全員によって『農業・農学の 展望』を取りまとめることとなり、山下興亜第6部 部長、松田籐四郎副部長のリードの下に、浅見輝男 会員と私が幹事として世話役を務め、東京農大出版 部より刊行出来た。体系的なまとまりという点では 劣るが、農学の全分野について、それぞれの領域を 代表する会員が、研究者や学生をはじめ、一般にも わかりやすく分担執筆するという、貴重な文献とな った。このような文献は少ないと思う。

この頃第18期全体としてては、政府内に出来た総 合科学技術会議の示唆を受け、日本学術会議の再編 の動きが表面化し、さまざまな議論が展開された。 吉川会長の科学者コミュニティの形成と「社会のた めの学術」といったビジョンが、明確な路線になっ
てきた。そしてこれに平行して新たな科学論の構築 が必要となり、吉田民人副会長を委員長とする委員 会が発足したが、ついに統一的見解を得るには至ら なかった。私自身は科学論には種々の立場が認めら れるべきで、統一は無理ではないかと推測していた が、結果はそのようになった。しかしこれらの議論 は決して無駄ではなく、科学と社会をめぐる科学者 の自覚と反省を促す機会にもなったと考える。

\section{第19期の活動について}

第20期が根本的改革の下に発足することが決定 していたので、第20期以降のあり方については発言 が控えられ、第19期は中途半端な感じもあった。し かし第6部の各委員は積極的に農業・農村・農学の 問題に取り組んだ。

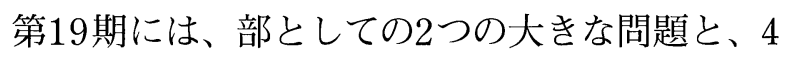
つの第6部専門委員会、そして数多くの研連がそれ ぞれの課題をめぐって、対外報告・答申・シンポジ ウム等の形で活動成果を出した。

1）「人口・食料・エネルギー」に関する総合的検討 では、少子化、そして高齢化の時代を迎える日本の 現実を前にして、そこでの食料やエネルギーの問題 について、独自の視点から考察・提言を行った。す なわち、ここでは少子化社会を、その是非を超えて 現実のものと捉え、これを機会に社会制度の全面的 な再編成を促し、食料・エネルギーの各地域・国に おける自給度の向上等を主張し、総じて「経済的発 展から文化的発展へ」と社会の軸足を移動する提言 が記されている。

2）先述したように「地球環境・人間生活にかかわ る水産業及び漁村の多面的な機能の内容及び評価に ついて」を、農林水産大臣に答申した。これに関連 
して、2004年度の東北大学での夏部会、日本学術 会議講堂での一般公開シンポジウム、福井県小浜市 での地域農学研連・近畿地区会議等主催のシンポジ ウムなど、いくつかのシンポジウムが開催された。 3）そのほか第6部の中に4つの專門委員会を設けた。 「農業生産の革新」「都市と農山漁村の新しい関係」 「食と農の安全体系」「流域圏生物システムの再構築」 などである。これらは関係研連と連帯して、対外報 告の提出、シンポジウムの開催などを行った。また 多くの研連が、それ攵れ委員会を設置して、対外報 告の作成、シンポジウムなどを行った。特にシンポ ジウムは、「社会のための学術」を理念とし、農業 の特質である「場所性」を反映して、各地域にマッ チした形で全国各地において、まさに草の根次元で 行われたところに特色がある。

4）また2005年京都での夏部会は、鳥インフルエン ザ、 $\mathrm{BSE}$ (牛海綿状脳症)、遺伝子組み換え食品等、 国民的な議論になっている問題について公開シンポ ジウムを行ったが、400名を超える参加があり、市 民の関心の広さを感じるとともに、農学の責任を痛 感した。

以上が第19期第6部の主たる活動であるが、第1 期から第18期までにも国内外の農林水産業につい て、それぞれの段階での主要問題を取り上げ、多く の貴重な報告、提言、勧告を行ってきている。これ らは学術会議の歴史をまとめた諸文献に見ることが 出来るので、ここには記載しない。

\section{今後の課題}

地球人口が現在の 63 億人から 90 億人へと増大す る中で、生産増大のための農地拡大と森林減少、既 存農地の過度な利用による塩類集積や地下水の枯
渴、さらには工業活動の活発化や生活の質的高度化 によるエネルギー問題、生態環境問題、食品の安全 性など、人類は後のない大きな矛盾と困難に直面し ている。これらのことは第18期の『日本の計画』、 第19期の『日本の科学技術政策の要諦』でも述べら れている。循環型社会に寄与する、持続的かつ効率 的農林水産業のための諸研究は、いまや大きな課題 となっている。

すなわち、化石資源に代わるバイオマス利用への 転換追求、新たな育種技術、環境調和型生産素材、 新食品素材及び加工プロセス等の開発、微生物利用 による環境保全や薬品開発、BSEや鳥インフルエン ザ等への対応、適切な食・住文化の形成、南北問題 や新しい農林水産物貿易関係構築への貢献等々であ る。これらは、日本の科学技術が日本国内だけでな く、国際社会に貢献していくべき課題として重視さ れる。持続的で安全・安心な社会の構築に向けて、 他の分野でも多くの課題が浮上しているが、その一 環として貢献していくことが必要である。

さらに農林水産業・農山漁村の多面的機能につい て、第 $18 \cdot 19$ 期は多くの貢献をしたが、今後さら に、海陸にわたる動植物資源の有効活用と保全、工 業を含む人類の活動とその限界、人間生活と自然と の適切な関係、流域の視点を重視した新たな都市・ 農村関係の構築、情報化時代における農業技術・農 村生活のあり方等が大きな課題となろう。

\section{結び}

今回の日本学術会議の改革をめぐって、「学術と 社会」、「俯㒈的視点の必要性」「領域と課題」といっ たことが大きな論議となった。第6部としては主と して次のような基本視点を繰り返し提起してきた。 
これまで経济価値の追求を中軸にし、あるいはそ れと連動してきた科学技術が、環境問題や生活の質 (真の豊かさ) などにも十分に配慮し、その調和的 追求へと軸足を移すことが、パラダイム転換の具体 的な姿だと考える。そこでは学際的、俯㒈的といっ た総合的視点が重視されることになる。

他方、科学は分化し細分化しつつ発展するという 宿命を背負う。「分化と総合」の相互性の上にこそ、 科学技術は正しく発展するといえよう。課題別編成 か、分野別編成かという議論は、二者択一でなく、 その両方に十分目配りしつつ両者の緊張関係の上に 活動を展開しなければならない。農学は生命系の総
合科学として、また実践的な実際科学として、まさ にこうした視点の上に立ち、海陸にわたる現実問題 と詨面しつつ展開してきたことを忘れてはならな い。

最後に、今後日本学術会議は、広く高邁な見地か ら独自の発言をして欲しい。武士は食わねど高楊枝 ふうに、単に自制するだけでなく、さまざまな問題 について、長期的、総合的視点から率直かつ適切な 方向提示をすることで、内外に打いて最も信頼でき る知識と知恵の集積拠点として進んで欲しいと願う ものである。

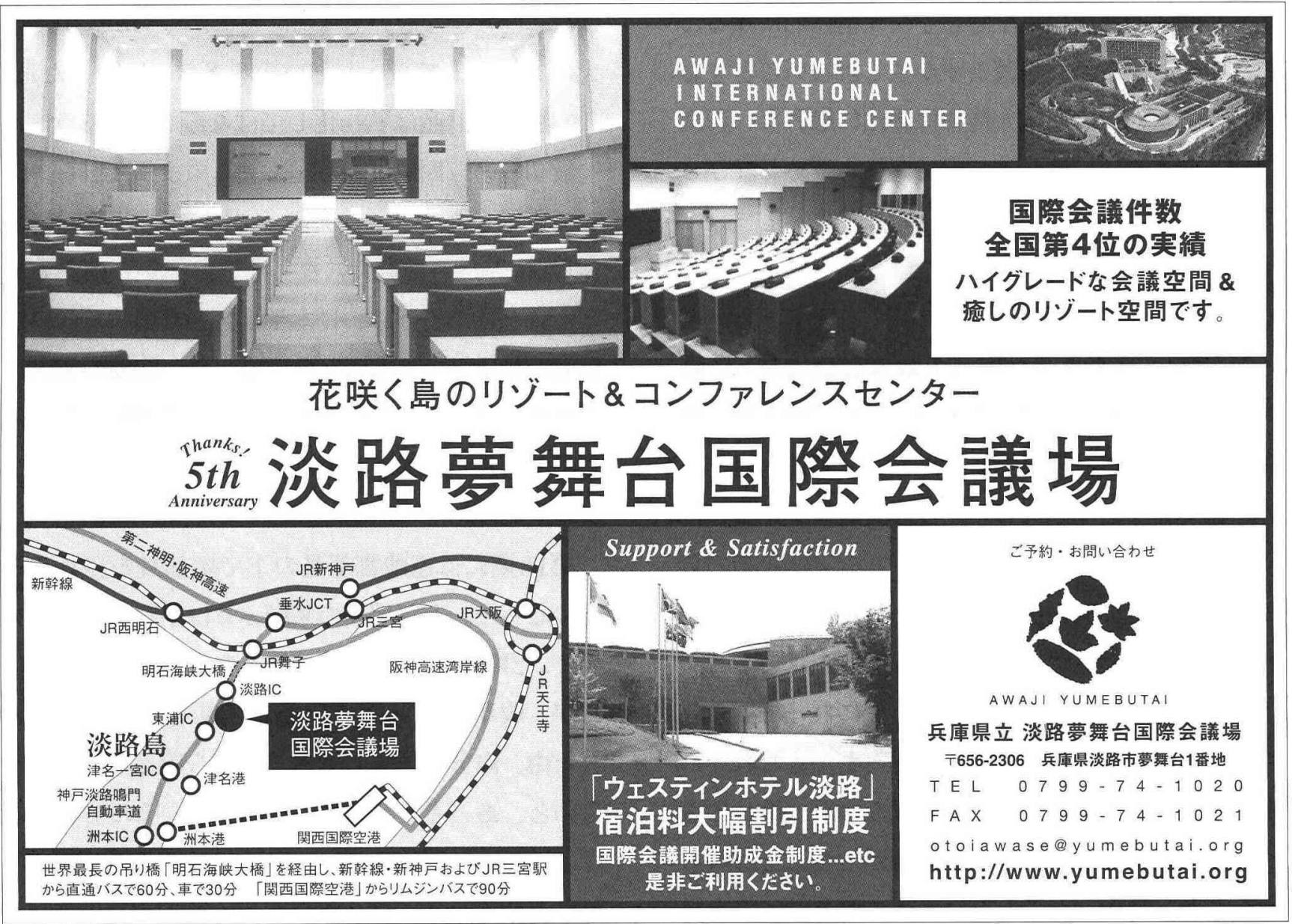

